\title{
Desain dan Implementasi Z-Source Inverter 3 Fasa dengan Metode Simple Boost Control untuk Suplai Motor Induksi
}

\author{
Rifki Dwisetyo Wicaksono, Dedet Candra Riawan dan Daniar Fahmi \\ Jurusan Teknik Elektro, Fakultas Teknologi Industri, Institut Teknologi Sepuluh Nopember (ITS) \\ J1. Arief Rahman Hakim, Surabaya 60111 \\ e-mail:dedet.riawan@ee.its.ac.id; daniar.fahmi@ee.its.ac.id
}

\begin{abstract}
Abstrak - Aplikasi dari energi terbarukan semakin banyak dikembangkan terutama penelitian mengenai photovoltaic dan fuel cell. Namun, kendala utama pada photovoltaic dan fuel cell yaitu memiliki tegangan keluaran yang rendah sehingga diperlukan sebuah konverter peningkat tegangan sebelum dapat diaplikasikan untuk inverter. Penggunaan inverter dengan penambahan topologi peningkat tegangan menyebabkan rugi - rugi konverter semakin besar. Selain itu, kendala utama pada topologi voltage source inverter yaitu tidak dapat beroperasi sebagai buck-boost konverter, diperlukannya dead time pada kontrol gate, dan kondisi shoot through zero state akan menyebabkan kerusakan pada inverter. Oleh karena itu, diperlukan desain topologi inverter yang memiliki kemampuan konversi boost dan tahan terhadap kondisi shoot through zero state. Z-Source inverter merupakan pengembangan dari voltage source inverter dengan penambahan rangkaian sumber impedansi dan kontrol penyalaan menggunakan simple boost control. Efisiensi ZSource inverter dapat mencapai $88 \%$. Faktor peningkatan tegangan dapat mencapai 2.4 kali dengan menggunakan shoot through duty ratio sebesar $16 \%$. Z-Source inverter mampu mengontrol kecepatan motor induksi berdasarkan v/f konstan dengan cara merubah nilai shoot through duty ratio dan frekuensi fundamental. Jadi inverter ini sangat cocok untuk diaplikasikan sebagai topologi dengan kemampuan meningkatkan tegangan input dan digunakan sebagai kontrol kecepatan motor induksi.
\end{abstract}

Kata Kunci - Motor Induksi, Simple Boost Control, Voltage Source Inverter, Z-Source Inverter.

\section{PENDAHULUAN}

$\mathrm{K}$ EBUTUHAN energi listrik setiap tahun mengalami peningkatan seiring dengan laju pertumbuhan penduduk. Pengembangan dan penelitian mengenai konversi energi listrik menjadi topik utama dari para peneliti dan industri, terutama energi yang berasal dari energi terbarukan. Pada saat ini sistem energi terbarukan yang paling banyak diteliti yaitu photovoltaic dan fuel cell. Kedua sistem energi terbarukan tersebut berbasiskan energi matahari dan hidrogen yang tidak menimbulkan pencemaran lingkungan.

Photovoltaic dan fuel cell telah banyak diteliti untuk dimanfaatkan pada mobil listrik. Kendala utama pada photovoltaic dan fuel cell adalah pada tegangan DC keluaran yang sangat rendah sehingga diperlukan konverter peningkat tegangan sebelum masuk ke rangkaian inverter [1,2]. Cara yang paling umum digunakan untuk meningkatkan tegangan DC yaitu menggunakan konverter Boost. Konverter Boost adalah alat yang digunakan untuk meningkatkan tegangan DC keluaran dari photovoltaic atau fuel cell dengan cara mengatur duty cycle. Semakin tinggi nilai duty cycle maka rasio peningkatan tegangan semakin besar.
Berbagai topologi inverter telah diusulkan untuk mendapatkan efisiensi konversi dan rasio peningkatan yang tinggi. Salah satunya yaitu dengan menggunakan dual stage boost voltage source inverter (VSI) atau current source inverter (CSI). Namun kelemahan dari topologi tersebut yaitu konversi secara dual stage menyebabkan efisiensi yang turun karena rugi - rugi switching semakin besar, gate driver harus didesain secara khusus agar pengaruh dari medan elektromagnetik dapat dihindari karena shoot through zero state pada topologi voltage source inverter dapat merusak komponen switching. Selain itu, pada topologi voltage source inverter tidak dapat beroperasi dalam mode buck-boost namun hanya dapat beroperasi dalam salah satu mode buck atau mode boost [3].

Untuk mengatasi permasalahan tersebut, maka penulis mengusulkan menggunakan topologi Z-source inverter dengan metode simple boost control. Z-source inverter merupakan salah satu topologi yang mampu meningkatkan rasio konversi tegangan hanya melalui satu topologi rangkaian. Dengan diterapkannya topologi ini diharapkan dapat meningkatkan efisiensi dari inverter yang digunakan untuk suplai dan kontrol kecepatan motor induksi 3 fasa.

\section{URAIAN PENELITIAN}

\section{A. Konfigurasi Sistem}

Diagram blok sistem mendefinisikan sistem keseluruhan dari Z-Source inverter dengan metode simple boost control untuk suplai motor induksi 3 fasa. Diagram blok terdiri dari sumber DC, sumber impedansi, komponen pensaklaran, driver MOSFET, simple boost control dan motor induksi 3 fasa seperti pada gambar 1 .

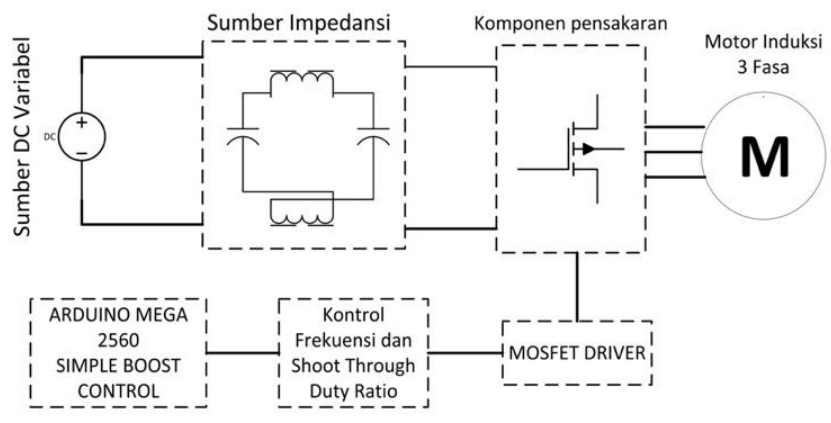

Gambar 1. Diagram Blok Keseluruhan Sistem Inverter

\section{B. Z-Source Inverter 3 Fasa}

$Z$-source converter merupakan sebuah jaringan impedansi yang terdiri dari dua buah induktor dan dua buah kapasitor yang terhubung secara silang. Z-source converter memiliki kemampuan sebagai peningkat (boost) maupun penurun 
(buck) tegangan tanpa memerlukan komponen switching tambahan. Selain sebagai peningkat atau penurun tegangan, jaringan impedansi tersebut berperan sebagai filter orde dua sehingga mampu mereduksi ripple tegangan, arus inrush serta harmonisa lebih baik. Jaringan impedansi tersebut dapat dihubungkan dengan sumber DC yang dapat berupa baterai, fuel cell maupun photovoltaic.

Z-source converter dapat diaplikasikan sebagai konverter DC ke AC, AC ke DC, AC ke AC dan DC ke DC. Pada umumnya, Z-Source converter digunakan sebagai converter DC ke AC yang membutuhkan faktor peningkatan maupun penurunan tegangan pada sisi output. Aplikasi Z-source inverter dapat dilihat pada gambar 2. Z-source inverter mampu meningkatkan tegangan output dengan menggunakan metode pensaklaran dengan menambahkan shoot-through zero states pada kontrol PWM [6].

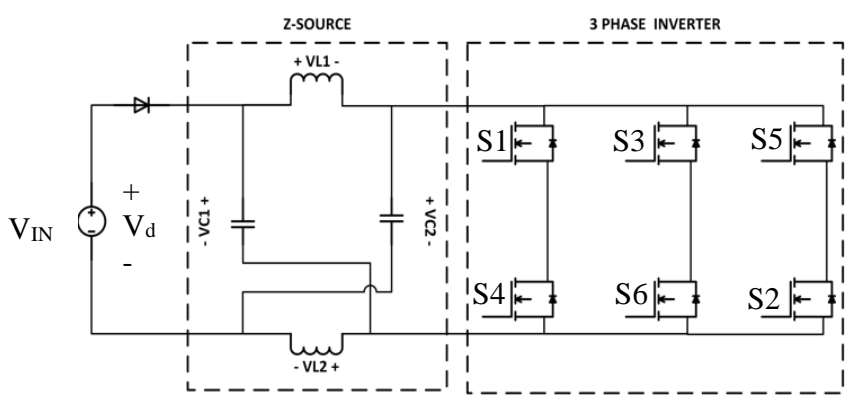

Gambar 2. Topologi Z-Source inverter 3 fasa.

Topologi Z-source inverter mampu mengatasi permasalahan pada inverter tradisional (CSI dan VSI). Pada VSI dan CSI, inverter tidak dapat beroperasi sebagai peningkat maupun penurun tegangan satu tingkat namun harus menggunakan proses konversi dua tingkat yaitu dengan menambahkan buck atau boost converter. Selain itu, gate driver harus didesain khusus untuk mengurangi pengaruh dari electromagnetic interference (EMI) yang menyebabkan kondisi shoot through zero state sehingga menyebabkan kerusakan pada VSI atau CSI. Topologi Z-source inverter hanya membutuhkan satu tingkat proses konversi tegangan, tidak memerlukan dead time dan penambahan shoot through sehingga tidak membuat inverter rusak $[3,6]$.

Tabel 1. Merupakan kondisi pensaklaran yang dapat digunakan pada $Z$ - Source inverter 3 fasa. Z-source inverter 3 fasa memiliki sembilan kondisi yang dapat berlaku dalam proses pensaklaran. Kondisi pensaklaran tersebut yang membedakan dengan voltage source inverter yang hanya memiliki delapan kondisi yang diperbolehkan [7].

Z-source inverter memiliki enam kondisi aktif ketika sumber DC mengalir melalui beban tiga fasa dan dua buah kondisi null yaitu ketika pada komponen pensaklaran bagian atas atau bawah mengalami kondisi hubung singkat. Kondisi kesembilan yaitu shoot through zero states yaitu kondisi dimana pada komponen pensaklaran bagian atas dan bawah mengalami hubung singkat. Pada kondisi kesembilan tersebut merupakan hal yang harus dihindari pada voltage source inverter untuk mencegah terjadinya hubung singkat pada inverter. Shoot through zero states didapatkan berdasarkan tujuh buah kombinasi hubung singkat yaitu melalui salah satu fasa pensaklaran, kedua buah fasa pensaklaran maupun ketiga fasa pensaklaran. Jaringan impedansi berfungsi sebagai peningkat rasio tegangan pada saat terjadi shoot through zero states. Terdapat beberapa teknik pensaklaran yang dapat digunakan pada $\mathrm{z}$-source inverter yaitu simple boost control, maximum boost control, dan maximum constant boost control with third harmonic injection $[4,8,9]$

Tabel 1.

Kondisi Pensaklaran pada Z-Source Inverter 3 Fasa (!Sx menyatakan komplemen dari Sx, dimana $X=1,3,5$ )

\begin{tabular}{|c|c|c|c|c|c|c|c|c|c|c|}
\hline \multirow{2}{*}{ No } & \multirow{2}{*}{ Kondisi } & \multicolumn{6}{|c|}{ Kompenen pensaklaran } & \multicolumn{3}{|c|}{ Output voltage } \\
\hline & & S1 & S4 & S3 & S6 & S5 & S2 & $\mathbf{V}_{\mathrm{ab}}$ & $\mathbf{V}_{\mathrm{bc}}$ & $\mathbf{V}_{\mathrm{ca}}$ \\
\hline 1 & \multirow{6}{*}{ 吾 } & 1 & 0 & 0 & 1 & 0 & 1 & $\mathrm{~V}_{\mathrm{i}}$ & 0 & $-V_{i}$ \\
\hline 2 & & 1 & 0 & 1 & 0 & 0 & 1 & 0 & $\mathrm{~V}_{\mathrm{i}}$ & $-V_{i}$ \\
\hline 3 & & 0 & 1 & 1 & 0 & 0 & 1 & $-V_{i}$ & $\mathrm{~V}_{\mathrm{i}}$ & 0 \\
\hline 4 & & 0 & 1 & 1 & 0 & 1 & 0 & $-V_{i}$ & 0 & $V_{i}$ \\
\hline 5 & & 0 & 1 & 0 & 1 & 1 & 0 & 0 & 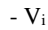 & $V_{i}$ \\
\hline 6 & & 1 & 0 & 0 & 1 & 1 & 0 & $\mathrm{~V}_{\mathrm{i}}$ & $-V_{i}-1-i$ & 0 \\
\hline 7 & \multirow{2}{*}{ Null } & 0 & 1 & 0 & 1 & 0 & 1 & 0 & 0 & 0 \\
\hline 8 & & 1 & 0 & 1 & 0 & 1 & 0 & 0 & 0 & 0 \\
\hline 9 & \multirow{7}{*}{ 离 } & 1 & 1 & S3 & !S3 & S5 & !S5 & 0 & 0 & 0 \\
\hline 10 & & S1 & !S1 & 1 & 1 & S5 & !S5 & 0 & 0 & 0 \\
\hline 11 & & S1 & !S1 & S3 & !S3 & 1 & 1 & 0 & 0 & 0 \\
\hline 12 & & 1 & 1 & 1 & 1 & S5 & !S5 & 0 & 0 & 0 \\
\hline 13 & & 1 & 1 & S3 & !S3 & 1 & 1 & 0 & 0 & 0 \\
\hline 14 & & S1 & !S1 & 1 & 1 & 1 & 1 & 0 & 0 & 0 \\
\hline 15 & & 1 & 1 & 1 & 1 & 1 & 1 & 0 & 0 & 0 \\
\hline
\end{tabular}

\section{Mode Operasi Konverter}

Berdasarkan kondisi pensaklaran pada tabel II, Z-source inverter dapat dibagi kedalam tiga buah mode operasi yaitu mode aktif, null dan shoot through zero states.

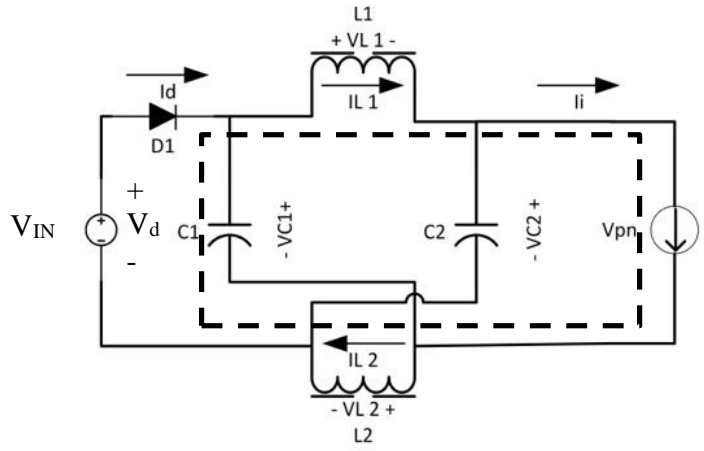

Gambar 3. Rangkaian Ekuivalen Z-Source Inverter pada Kondisi Aktif

Mode I: inveter beroperasi dalam salah satu mode aktif dan rangkaian ekuivalen dapat dilihat pada gambar 3. Selama dalam kondisi aktif, sumber DC mengalir ke rangkaian impedansi yang terdiri dari induktor dan kapasitor. Kapasitor akan mengalami charge hingga kondisi steady state dan energi akan mengalir ke beban melalui induktor. Induktor mengalami discharge pada mode ini.

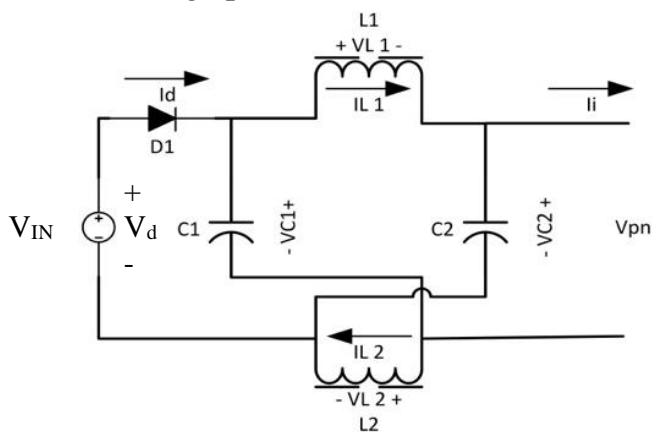

Gambar 4. Rangkaian Ekuivalen Z-Source Inverter pada Kondisi Null

Mode II: Inverter beroperasi dalam salah satu dari dua keadaan null yaitu komponen pensaklaran mengalami hubung singkat pada bagian atas atau bawah. Selama mode II, rangkaian dapat diasumsikan sebagai open circuit seperti pada gambar 4. Tegangan pada sumber DC akan menuju induktor dan kapasitor. 


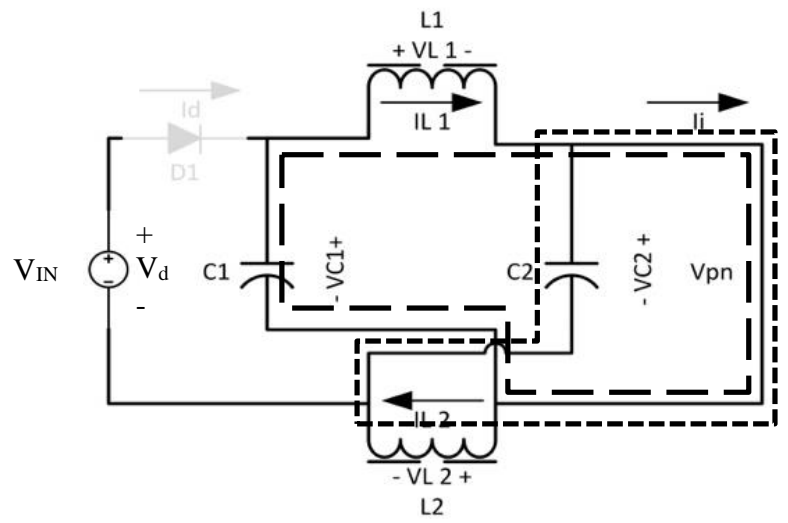

Gambar 5. Rangkaian Ekuivalen Z-Source Inverter pada Kondisi Shoot Through Zero States

Mode III: Inverter beroperasi dalam salah satu dari tujuh keadaan shoot through zero states. Pada mode III, rangkaian dapat diasumsikan sebagai short circuit seperti pada gambar 5. Selama mode III, tidak terdapat tegangan keluaran pada inverter sama seperti dengan kondisi mode II. Tegangan DC kapasitor akan meningkat sesuai dengan besarnya rasio shoot through duty ratio.

\section{Analisis Penurunan Rasio Konversi}

Penurunan persamaan pada z-source inverter dilakukan dengan asumsi nilai induktor $\mathrm{L}_{1}$ dan $\mathrm{L}_{2}$ serta kapasitor $\mathrm{C}_{1}$ dan $\mathrm{C}_{2}$ memiliki nilai yang sama $\left(\mathrm{L}_{1}=\mathrm{L}_{2}=\mathrm{L}\right.$ dan $\left.\mathrm{C}_{1}=\mathrm{C}_{2}=\mathrm{C}\right)$. Pada saat kondisi shoot through zero states $\left(\mathrm{T}_{0}\right)$ maka arus induktor akan mengalami peningkatan dan tegangan pada induktor akan muncul sedangkan pada saat kondisi non shoot through zero states $\left(\mathrm{T}_{1}\right)$ maka arus induktor akan menurun dan tegangan induktor akan bernilai nol.

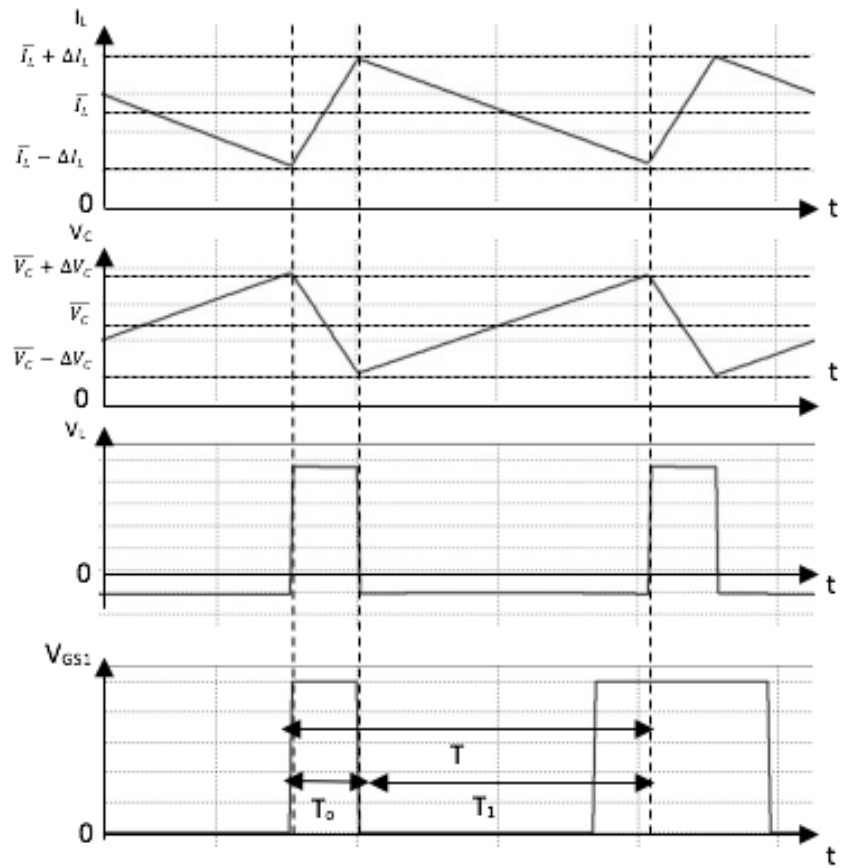

Gambar 6. Sinyal Pensaklaran pada Tegangan dan Arus Induktor dari ZSource Inverter

Sehingga persamaan tegangan pada impedansi z-source inverter dapat dituliskan sebagai berikut:

$$
\left\{\begin{array}{l}
V_{L 1}=V_{L 2}=V_{L} \\
V_{C 1}=V_{C 2}=V_{C}
\end{array}\right.
$$

Pada saat mode III yaitu shoot through zero states dengan interval waktu $T_{o}$. Berdasakan hukum khirchoff maka persamaan tegangan dapat dituliskan sebagai berikut:

$$
\left\{\begin{array}{c}
V_{L}=V_{C} \\
V_{d}=2 V_{C} \\
V_{P N}=0(\text { Shoot Through })
\end{array}\right.
$$

Pada saat mode I dan II yaitu saat kondisi aktif dan null dengan interval waktu $T_{l}$. Berdasarkan hukum khirchoff maka persamaan tegangan dapat dituliskan sebagai berikut:

$$
\left\{\begin{array}{c}
V_{L} \neq V_{C}, V_{d}=V_{\text {in }}=V_{L}+V_{C} \\
V_{L}=V_{\text {in }}-V_{C}=V_{C}-V_{P N} \\
V_{P N}=V_{C}-V_{L}=2 V_{C}-V_{\text {in }}
\end{array}\right.
$$

Pada saat kondisi steady state, tegangan rata - rata pada induktor adalah nol selama satu periode pensaklaran. Sehingga persamaan tegangan dapat dituliskan sebagai berikut:

$$
\begin{aligned}
& \bar{V}_{L}=V_{C} * T_{o}+\left(V_{i n}-V_{C}\right) * T_{1}=0 \\
& \frac{V_{C}}{V_{\text {in }}}=\frac{T_{1}}{T_{1}-T_{0}}
\end{aligned}
$$

Dimana $T_{1}$ adalah periode saat kondisi non shoot through, $T_{o}$ adalah periode saat shoot through zero states dan $f_{s}$ adalah frekuensi pensaklaran. Maka periode shoot through zero states dapat dicari menggunakan persamaan berikut:

$$
\begin{aligned}
& D_{o}=T_{o} * f_{s} \\
& T_{o}=D_{o} / f_{s}
\end{aligned}
$$

Sehingga persamaan tegangan DC rata - rata pada masukan inverter $\left(\mathrm{V}_{\mathrm{PN}}\right)$ dapat dituliskan sebagai berikut:

$$
\begin{aligned}
& \bar{V}_{P N}=\frac{T_{0} * 0+T_{1} *\left(2 V_{C}-V_{i n}\right)}{T} \\
& \bar{V}_{P N}=\frac{T_{1} *\left(2 V_{C}-V_{i n}\right)}{T} \\
& \bar{V}_{P N}=\frac{T_{1}}{T_{1}-T_{0}} V_{i n}
\end{aligned}
$$

dengan substitusi ke persamaan 3 maka didapatkan

$$
\bar{V}_{P N}=\frac{T_{1}}{T_{1}-T_{0}} V_{\text {in }}=V_{C}
$$

Nilai puncak dari DC link pada kondisi non shoot through zero states yaitu

$$
V_{P N}=V_{C}-V_{L}=2 * V_{C}-V_{\text {in }}
$$

Substitusi $V_{C}$ dari persamaan 6 ke persamaan 7 maka didapatkan

$$
\overline{V_{p n}}=\frac{T}{T_{1}-T_{0}} V_{\text {in }}=B * V_{\text {in }}
$$

Dimana $B$ ada faktor peningkat tegangan

$$
B=\frac{T}{T_{1}-T_{0}}=\frac{1}{1-\left(2 \frac{T_{0}}{T}\right)} \geq 1
$$

$\left(T_{1}+T_{0}=T\right)$

Sehingga tegangan maksimum fasa ke netral yaitu

$$
\overline{V_{a c}}=\frac{M * \overline{V_{P N}}}{2}=\frac{M * B * V_{i n}}{2}
$$

Dimana $M$ adalah indeks modulasi $(M \leq 1)$

Dengan mengubah nilai shoot through duty ratio maka faktor peningkatan tegangan $(B)$ dapat diubah - ubah $[4,10,11]$.

\section{E. Induktor}

Pada saat Z-Source inverter dioperasikan tanpa shoot through zero states maka tegangan input akan muncul pada kapasitor sedangkan pada induktor tidak muncul tegangan karena arus yang mengalir pada induktor adalah DC murni. 


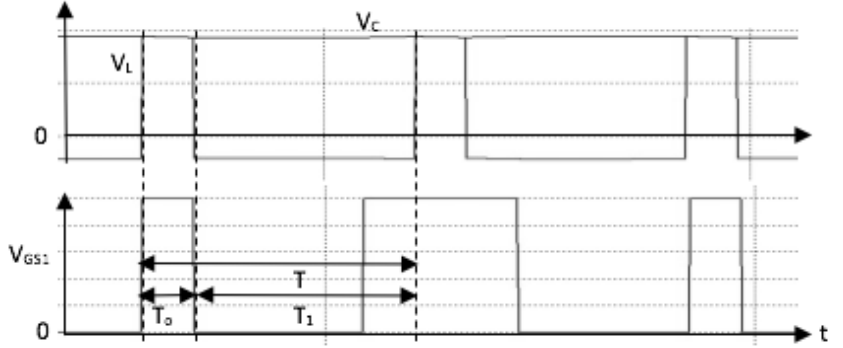

Gambar 7. Perbandingan Tegangan Kapasitor dan Tegangan Induktor

Pada saat Z-Source inverter dioperasikan menggunakan shoot through states maka induktor berfungsi untuk membatasi arus ripple selama mode boost. Selama mode shoot through zero states, arus induktor bertambah secara linear dan tegangan pada induktor sama dengan pada kapasitor seperti pada gambar 7. Pada saat mode non shoot through zero states ( 8 mode tradisional) maka arus pada induktor akan berkurang secara linear dan nilai tegangan induktor tidak sama dengan tegangan input dan kapasitor.

Nilai arus rata - rata pada induktor yaitu:

$$
\overline{I_{L}}=\frac{P}{V_{\text {in }}}
$$

Dimana $\mathrm{P}$ adalah total daya inverter

Nilai arus induktor maksimum terjadi pada saat Z-Source inverter pada mode Shoot Through Zero States. Untuk menentukan nilai induktor maka perlu ditentukan nilai peak to peak arus ripple $\left(\Delta I_{L}\right)$.

Nilai maksimum arus induktor: $\widehat{I}_{L}=\overline{I_{L}}+0.5 \Delta I_{L}$

Nilai minimum arus induktor: $\widetilde{I}_{L}=\bar{I}_{L}-0.5 \Delta I_{L}$

Selama mode Shoot Through Zero States maka nilai $V_{L}=V_{C}=V$

$$
V=\frac{V_{\text {in }}+B * V_{\text {in }}}{2}
$$

Sehingga nilai induktor dapat ditentukan menggunakan rumus

$$
L=\frac{V * T_{0}}{\Delta I}
$$

$\operatorname{dimana} \Delta I_{L}=\widehat{I}_{L}-\widetilde{I}_{L}$

$T_{0}$ adalah periode shoot through zero states per switching cycle dan dapat dihitung menggunakan persamaan 5 .

\section{F. Kapasitor}

Kapasitor pada Z-Source Inverter berfungsi untuk menyerap arus ripple dan sebagai penstabil tegangan. Induktor akan diisi oleh kapasitor ketika z-source inverter berada pada mode shoot through seperti yang telah dijelaskan pada mode III dan $I_{L}=I_{C}$.

Nilai kapasitor dapat dihitung dengan cara menentukan peak to peak ripple tegangan pada kapasitor $\left(\Delta V_{C}\right)$. Sehingga nilai kapasitor dapat dihitung menggunakan rumus

$$
C=\frac{\overline{I_{L}^{*}} T_{0}}{\Delta V_{C}}
$$

\section{G. Stres Tegangan dan Arus pada Komponen}

Stres tegangan dan arus pada setiap dapat dihitung pada saat kondisi shoot through zero state [11]. Stres tegangan pada setiap kapasitor dan induktor dapat dicari menggunakan persamaan 6 yaitu

$$
\begin{aligned}
& V_{L}=V_{C}=\frac{T_{1}}{T_{1}-T_{0}} V_{i n} \\
& V_{L}=V_{C}=\frac{1-D_{o}}{1-2 D_{o}} V_{i n}
\end{aligned}
$$

Sedangkan nilai arus maksimum pada induktor dapat dicari menggunakan persamaan 11

$$
\begin{aligned}
& \overline{I_{L}}=\frac{P}{V_{\text {in }}} \\
& \overline{I_{L \max }}=\overline{I_{L}}+\widehat{I_{L}}
\end{aligned}
$$

Stress tegangan pada komponen semikonduktor dioda dan mosfet dapat dicari menggunakan persamaan 8

$$
V_{\boldsymbol{d}}=V_{\boldsymbol{D S}}=\overline{V_{p n}}=B * V_{\text {in }}
$$

Sedangkan nilai arus maksimum yang mengalir pada dioda dan $\mathrm{DC}$ bus $\left(\mathrm{V}_{\mathrm{PN}}\right)$ yaitu

$$
I_{i}=2 I_{l}
$$

Maka arus yang mengalir pada setiap mosfet yaitu

$$
\begin{aligned}
& 2 I_{l}=\frac{3 * \widehat{V_{a c}} * \widehat{a c} * \cos \varphi}{V_{i n}}+\frac{V_{C} * D_{O}}{2 L f_{S}} \\
& I_{\text {mosfet }}=\frac{\widehat{\widehat{a c}} * \widehat{l a c}^{*} * \cos \varphi}{V_{\text {in }}}+\frac{V_{C} * D_{O}}{6 L f_{S}}
\end{aligned}
$$

\section{H. Simple Boost Control}

Simple boost control merupakan sinusoida PWM yang dimodifikasi dengan cara menambahkan shoot through zero state dalam satu periode switching.

Shoot through zero states dibatasi dengan besarmya kondisi ketika saklar tidak aktif dan kemungkinan menggantikan sebagian maupun semua kondisi aktif yang bergantung pada besarnya indeks modulasi. Dua buah sinyal DC digunakan untuk membuat shoot through duty ratio $\left(D_{o}\right)$. Sinyal DC yang pertama yaitu sama berada pada sisi positif dari sinyal refrensi tiga fasa, sedangkan sinyal DC yang kedua adalah negatif dari sinyal DC yang pertama. Ketika sinyal pembawa segitiga lebih besar dari pada sinyal DC positif $\left(V_{p o}\right)$ dan lebih kecil dari pada sinyal DC batas bawah $\left(V_{n e}\right)$ maka rangkaian akan berada dalam keadaan shoot through [5]. Simple boost control PWM dapat diilustrasikan pada gambar 8 .

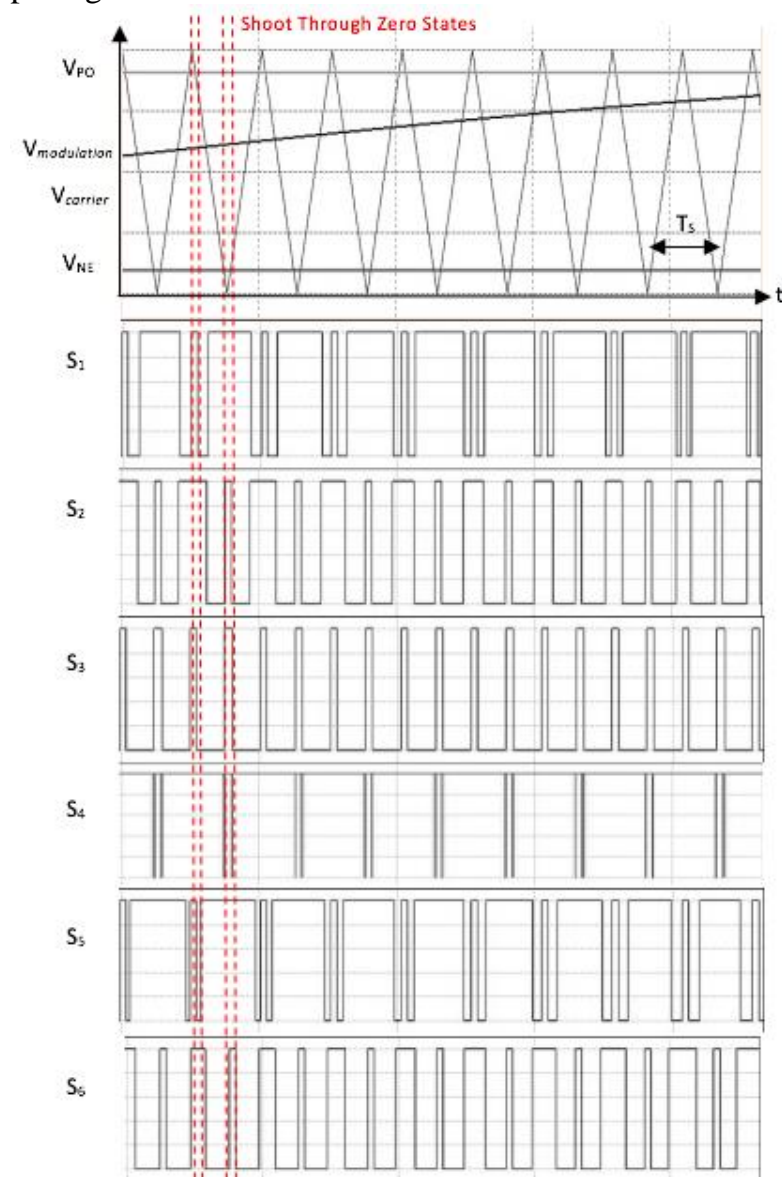

Gambar 8. Pensaklaran PWM dari Simple Boost Control 


\section{DESAIN DAN IMPLEMENTASI}

\section{A. Desain}

Desain inverter bertujuan untuk menentukan parameter awal dari inverter dengan mempertimbangkan kondisi peralatan yang ada dilaboratorium dan ketersediaan komponen yang ada di pasaran untuk mempermudah proses implementasi inverter. Menentukan parameter awal inverter berpengaruh terhadap nilai kapasitas komponen seperti kapasitor, induktor dan nilai shoot through duty cycle yang digunakan sebagai control inverter. Tabel 2 dibawah ini merupakan parameter awal untuk mendesain inverter. Tegangan input dan daya inverter ditentukan berdasarkan sumber DC yang tersedia pada laboratorium. Dengan adanya keterbatasan alat pembebanan motor induksi dan sumber DC di laboratorium konversi energi listrik maka desain inverter dibuat $250 \mathrm{~W}$ dengan tegangan masukan $48 \mathrm{~V}$.

Tabel 2.

Spesifikasi Awal Desain Inverter

\begin{tabular}{ll}
\hline \hline Parameter & Nilai \\
\hline Daya maksimum, $\mathrm{P}_{\text {out_max }}$ & 250 Watt \\
Tegangan masukan, $\mathrm{V}_{\text {in }}$ & 48 Volt \\
Tegangan Keluaran, $\mathrm{V}_{\text {LLrms }}$ & 56 Volt \\
Frekuensi output, $\mathrm{f}_{\mathrm{o}}$ & $50 \mathrm{~Hz}$ \\
Indeks modulasi, $\mathrm{M}$ & 0.8 \\
Frekuensi Pensaklaran, $\mathrm{f}_{\mathrm{s}}$ & $7.842 \mathrm{kHz}$ \\
Ripple tegangan kapasitor, $\mathrm{V}_{\text {kapasitor }}\left(\Delta \mathrm{V}_{\mathrm{C}}\right)$ & $0,5 \%$ \\
Ripple arus induktor, $\mathrm{I}_{\mathrm{L} \text { peak to peak }}$ & $20 \%$ \\
\hline \hline
\end{tabular}

Faktor peningkatan tegangan $(B)$ yang dibutuhkan untuk mendapatkan tegangan keluaran line to line sebesar $56 \mathrm{Vrms}$ dan dengan menggunakan nilai indeks modulasi 0.8 maka faktor peningkatan tegangan dapat dihitung menggunakan persamaan 10

$$
\begin{aligned}
& B=\frac{\sqrt{2} 56}{\sqrt{3}} \times \frac{2}{0.8 * 48} \\
& B=2.4
\end{aligned}
$$

maka nilai shoot through duty ratio dapat didapatkan menggunakan persamaan 9

$$
\begin{aligned}
& B=\frac{1}{1-2 D_{o}} \\
& D_{o}=\frac{B-1}{2 B} \\
& D_{o}=\frac{2.4-1}{2 * 2.4} \\
& D_{o}=0.291
\end{aligned}
$$

Degan menggunakan frekuensi pensaklaran $7.842 \mathrm{KHz}$ maka periode shoot through dapat dihitung menggunakan persamaan 5

$$
\begin{aligned}
& D_{o}=T_{o} * f_{s} \\
& T_{o}=D_{o} / f_{s} \\
& T_{o}=\frac{0.291}{7.842 * 10^{3}}=37.1 \mu \mathrm{s}
\end{aligned}
$$

Nilai induktor minimum untuk memperoleh nilai ripple pada arus induktor sebesar $10 \%$ dapat digunakan menggunakan persamaan 12 dan 13. Pertama arus rata - rata pada induktor dapat dihitung menggunakan persamaan 11

$$
\begin{aligned}
& \overline{I_{L}}=\frac{P}{V_{i n}} \\
& \overline{I_{L}}=\frac{250}{48}=5.21 \mathrm{~A}
\end{aligned}
$$

dengan menentukan ripple $20 \%$ (peak to peak) maka arus induktor yaitu:

$$
\begin{aligned}
& \overline{I_{L \max }}=5.21+10 \%=5.731 \mathrm{~A} \\
& \overline{I_{L m i n}}=5.21-10 \%=4.689 \mathrm{~A} \\
& \overline{\Delta I_{L}}=2 * 0.521=2.08 \mathrm{~A}
\end{aligned}
$$

Tegangan pada komponen induktor pada saat shoot through dapat dihitung dengan menggunakan persamaan 6

$$
\begin{aligned}
V_{L} & =\left(\frac{1-D_{o}}{1-2 D_{o}}\right) V_{\text {in }} \\
V_{L} & =\left(\frac{1-0.291}{1-2 * 0.291}\right) 48 \\
V_{L} & =81.5 \mathrm{~V}
\end{aligned}
$$

maka dengan menggunakan persamaan 14 didapatkan nilai induktor sebesar

$$
L=\frac{81.5 * 371 * 10^{-6}}{2.4}=1.45 \mathrm{mH}
$$

Nilai kapasitor minimum dapat ditentukan dengan menentukan besar ripple tegangan pada kapasitor. Pada saat shoot through maka nilai dari $\mathrm{I}_{\mathrm{L}}=\mathrm{I}_{\mathrm{C}}$ dan dipilih ripple sebesar $0.5 \%$. Sehingga dengan persamaan 16 maka nilai kapasitor yang dibutuhkan sebesar

$$
\begin{aligned}
& C=\frac{\overline{\Delta I_{L}} * T_{O}}{\Delta V_{C}} \\
& C=\frac{5.21 * 371 * 10^{-6}}{81.5 * 0.5 \%} \\
& C=474.8 \mu \mathrm{F}
\end{aligned}
$$

\section{B. Hasil Implementasi}

Berdasarkan perhitungan hasil desain, maka komponenkomponen yang diperlukan dapat dilihat pada tabel 4 .

Nilai implementasi komponen disesuaikan dengan ketersediaan komponen yang ada di pasaran. Nilai pada komponen implementasi merupakan nilai yang lebih besar dari nilai komponen yang telah didesain. Hal tersebut bertujuan untuk mengantisipasi voltage spike pada inverter.

Tabel 4.

Parameter Komponen Inverter Implementasi

\begin{tabular}{ll}
\hline Komponen Z-Source Inverter & Nilai \\
\hline Induktor $\mathrm{L}_{1}$ dan $\mathrm{L}_{2}$ & $1.6 \mathrm{mH}$ \\
Kapasitor $\mathrm{C}_{1}$ dan $\mathrm{C}_{2}$ & $416 \mu \mathrm{F} / 400 \mathrm{~V}$ \\
Dioda & MUR1560 \\
Mosfet $(\mathrm{S} 1$ - S6) & IRFP460LC \\
Simple Boost Control dan Gate Driver & Nilai \\
\hline Micro Controller & Arduino Mega \\
IC or Logic & $74 \mathrm{HCT} 04$ \\
IC not Logic & $74 \mathrm{HCT} 32$ \\
Gate Driver & FOD3182V \\
Gate Supply & $12 \mathrm{Vdc}$ \\
\hline
\end{tabular}

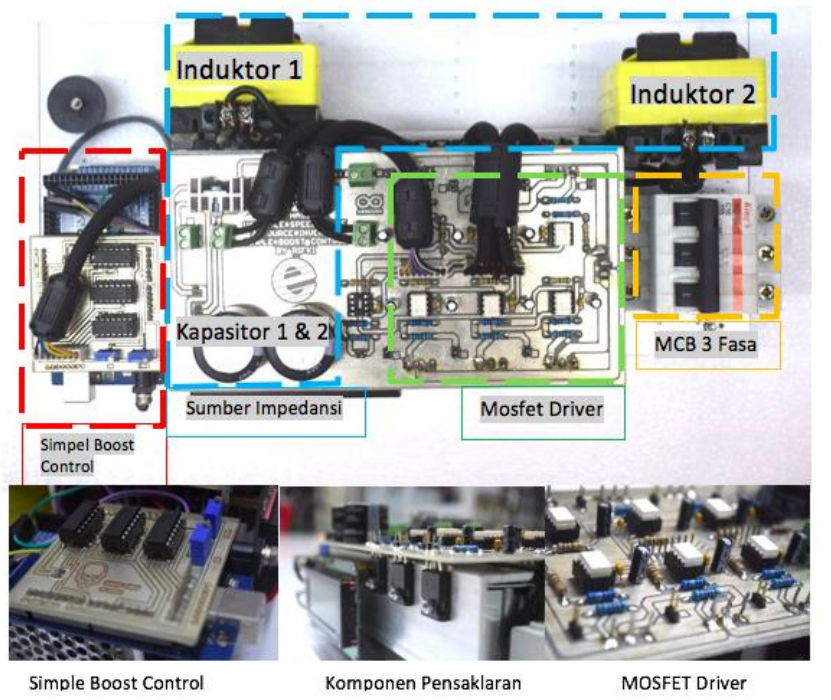

Gambar 9. Hasil Implementasi Z-Source Inverter 3 Fasa

Hasil implementasi Z-Source inverter dengan metode simple boost control yang sudah dirangkai dapat dilihat pada 
gambar 9. Pada gambar diatas inverter dibagi menjadi 4 rangkain utama. Bagian pertama yaitu power supply sebagai penyuplai tegangan pada driver MOSFET. Bagian kedua yaitu MOSFET dan arduino mega 2560 sebagai sistem pensaklaran utama konverter. Bagian keempat yaitu sumber impedansi yang terdiri dari induktor dan kapasitor sebagai sistem peningkat rasio konversi.

\section{PENGUJIAN}

\section{A. Pengujian Pada Motor Induksi 3 Fasa}

Pengujian dilakukan untuk mengetahui performa dari hasil implementasi Z-Source Inverter ke motor induksi 3 fasa. Pengujian pembebanan motor induksi dilakukan dengan cara memberikan tegangan input konstan sebesar $48 \mathrm{~V}$, indeks modulasi sebesar 0.8, frekuensi output sebesar $50 \mathrm{~Hz}$ dan shoot through duty ratio dinaikan secara bertahap untuk menjaga tegangan output tetap konstan. Dengan keterbatasan alat pengereman di laboratorium maka pembebanan motor induksi dinaikan secara bertahap dari 0 N.m hingga 0.6 N.m.

Berdasarkan hasil pengujian Z-Source inverter dengan motor induksi didapatkan data seperti pada tabel 5. Pada saat motor induksi tidak diberi beban maka inverter membutuhkan nilai shoot through duty ratio sebesar 0.12 dan apabila beban semakin naik untuk mendapatkan tegangan output konstan sebesar $56 \mathrm{~V}$ maka nilai shoot through duty ratio juga naik. Apabila hasil implementasi dibandingkan dengan hasil desain dan simulasi maka terdapat ketidak sesuaian. Pada desain dan simulasi untuk mendapatkan tegangan konstan $56 \mathrm{~V}$ dibutuhkan nilai shoot through duty ratio sebesar 0.291. Namun, pada implementasi hanya dibutuhkan nilai shoot through duty ratio yang lebih rendah daripada hasil desain. Perbedaan pada saat implementasi dan simulasi diakibatkan oleh adanya fenomena self boost. Fenomena self boost muncul pada Z-Source inverter diakibatkan memenuhi persamaan dibawah ini.

$$
M \cos \emptyset<\frac{2}{3}
$$

Selama pada nilai perkalian antara indeks modulasi dengan faktor daya kurang dari 2/3 maka akan kondisi shoot through zero states yang tidak diharapkan. Pada implementasi adanya pengaruh self boost secara grafik dapat dilihat pada gambar 12 .

Tabel 5.

Hasil pengujian Z-Source Inveter pada pembebanan motor induksi 3 fasa dengan $\mathrm{V}_{\mathrm{IN}}=48 \mathrm{~V}, \mathrm{M}=0.8, \mathrm{f}=50 \mathrm{~Hz}$

\begin{tabular}{ccccccccccc}
\hline \hline $\mathbf{I}_{\mathbf{I N}}$ & $\mathbf{D}_{\mathbf{O}}$ & $\mathbf{R P M}$ & $\boldsymbol{\tau}$ & $\mathbf{P F}$ & $\mathbf{V}_{\mathbf{P N}}$ & $\mathbf{V o}$ & $\mathbf{I o}$ & THD & $\mathbf{P}_{\mathbf{I N}}$ & Po \\
\hline 0.9 & 0.12 & 1480 & 0.0 & 0.27 & 140 & 56 & 1.5 & 2.1 & 43 & 38 \\
1.1 & 0.12 & 1475 & 0.1 & 0.29 & 140 & 56 & 1.5 & 2.1 & 53 & 47 \\
1.4 & 0.13 & 1465 & 0.2 & 0.43 & 130 & 56 & 1.5 & 2.2 & 66 & 58 \\
1.7 & 0.14 & 1457 & 0.3 & 0.46 & 130 & 56 & 1.6 & 2.3 & 84 & 74 \\
2.1 & 0.16 & 1445 & 0.4 & 0.49 & 123 & 56 & 1.8 & 2.0 & 102 & 90 \\
2.5 & 0.16 & 1436 & 0.5 & 0.53 & 120 & 56 & 2.0 & 2.0 & 120 & 106 \\
3.0 & 0.16 & 1423 & 0.6 & 0.56 & 115 & 56 & 2.2 & 2.0 & 144 & 125 \\
\hline \hline
\end{tabular}

Pada kurva gambar 12 menunjukkan bahwa nilai perkalian antara indeks modulasi dengan faktor daya semakin mendekati 2/3 maka nilai peningkatan tegangan akan mendekati nilai pada hasil desain dan simulasi. Hal ini membuktikan bahwa fenomena self boost dapat dikurangi dengan menaikkan faktor daya beban. [17]

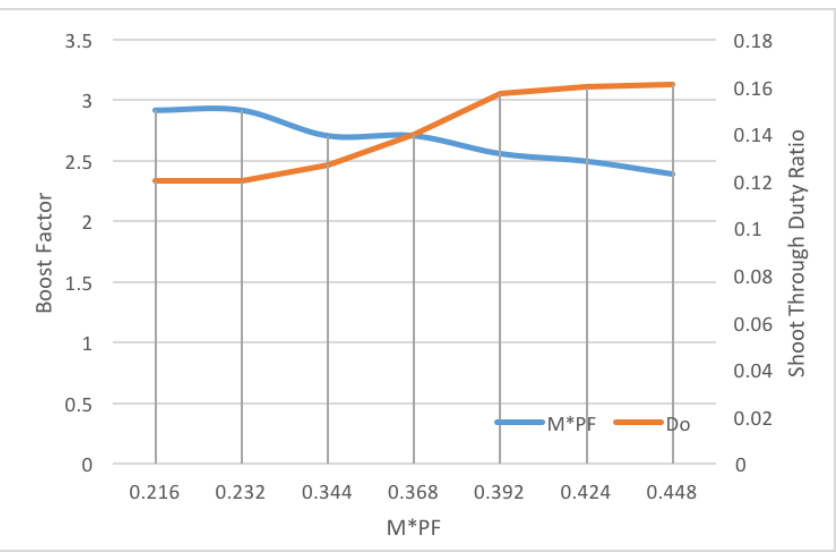

Gambar 12. Kurva Pengaruh Self Boost pada Z-Source Inverter

\section{B. Pengujian Efisiensi Z-Source Inverter}

Pengujian efiseinsi dilakukan untuk mengetahui pengaruh performa inverter terhadap pembebanan yang berubah ubah. Pada hasil implementasi pembebanan motor induksi dapat diukur efisiensi inverter dengan cara membandingkan daya input dengan daya output inverter. Pengujian efisiensi inverter dilakukan dengan cara menaikan beban motor induksi dari 0 N.m hingga 0.6 N.m.

Inverter memiliki efisiensi rata - rata sebesar $88 \%$ dan grafik pengaruh pembebanan terhadap efisiensi inverter dapat dilihat pada gambar 13 Semakin besar pembebanan maka efisiensi inverter akan menurun. Hal ini disebabkan adanya rugi - rugi yang semakin besar karena arus yang mengalir ke rangkaian akan meningkat seiring dengan naiknya beban. Rugi -rugi yang terjadi pada inverter antara lain switching loss, rugi pada inti induktor, rugi pada dioda fast switching dan charge-dischage kapasitor.

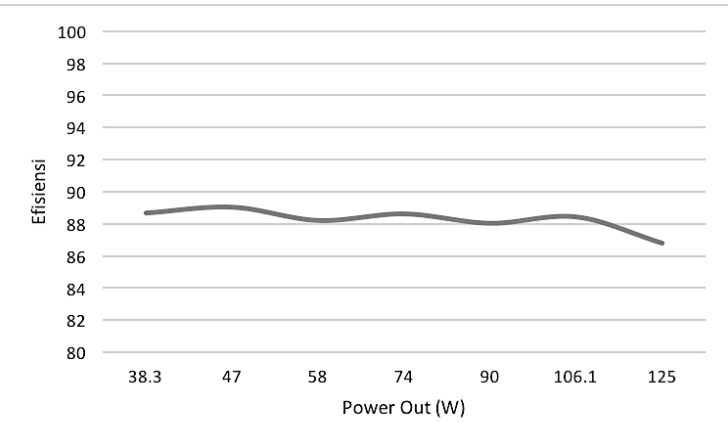

Gambar 13. Kurva Pengaruh Pembenan terhadap Efisiensi Inverter

\section{Pengujian Faktor Peningkatan Tegangan}

Pengujian rasio konversi bertujuan untuk mengetahui faktor peningkatan tegagan pada Z-Source Inverter dengan metode simple boost control. Faktor peningkatan tegagan (B) merupakan perbandingan antara tegangan dc bus dengan tegangan input. Secara teori semakin besar nilai shoot through duty ratio, maka semakin besar rasio konversi sehingga tegangan output yang dihasilkan oleh inverter semakin tinggi. Pengujian rasio konversi dengan cara memberikan tegangan input konstan sebesar Vin $=48 \mathrm{~V}$ dan shoot through duty ratio dinaikkan secara bertahap. Z-Source inverter dibebani dengan motor induksi 3 fasa dan torsi pembebanan 0 N.m.

Gambar 14 menunjukkan grafik antara tegangan output line to line rms dengan shoot through duty ratio. Berdasarkan hasil implementasi didapatkan semakin besar nilai shoot through duty ratio maka faktor peningkatan tegangan semakin meningkat. Namun, apabila dibandingan hasil 
implementasi dan teori maka terdapat perbedaan. Perbedaan hasil tersebut diakibatkan nilai faktor daya yang sangat rendah yaitu sebesar 0.27 . Selain itu, pada setiap komponen seperti kapasitor, induktor, dioda dan MOSFET memiliki hambatan dalam. Resistansi pada tiap komponen mengakibatkan drop tegangan. Semakin besar nilai shoot through duty cycle maka semakin besar pula nilai arus yang mengalir sehingga drop tegangan akan semakin besar pula.

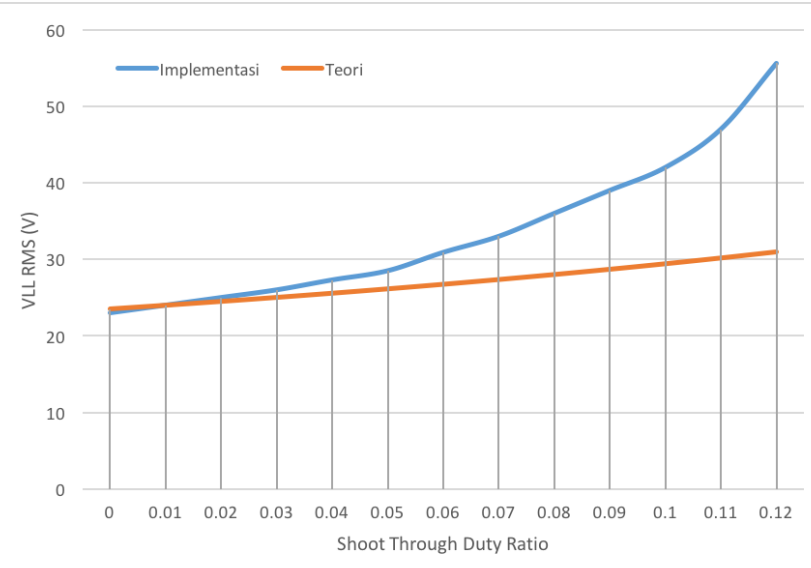

Gambar 14. Grafik Pengujian Rasio Peningkatan Tegangan

\section{Pengujian Kontrol Kecepatan Motor Induksi}

Pengujian Z-Source Inverter sebagai kontrol kecepatan motor induksi dilakukan dengan cara memberi tegangan masukan sebesar $48 \mathrm{~V}$ dan nilai indeks modulasi 0.8 sedangan nilai shoot through duty ratio dan frekuensi fundamental dibuat berubah - ubah sesuai dengan aturan V/f konstan. Pengujian kontrol kecepatan dilakukan dengan motor induksi dalam keadaan tanpa beban.

Tabel 6.

Hasil Pengujian Z-Source Inverter sebagai Kontrol Kecepatan Motor Induksi untuk $\mathrm{V}_{\text {in }}=48 \mathrm{~V}, \mathrm{M}=0.8$ dan $\tau=0 \mathrm{~N}$.m

\begin{tabular}{cccccccccc}
\hline \hline In & Do & f & RPM & PF & Vpn & B & $\mathbf{V}_{\text {rms }}$ & $\mathbf{I}_{\text {rms }}$ & Po \\
\hline 0.49 & 0.032 & 25 & 731 & 0.27 & 80 & 1.6 & 28.0 & 1.5 & 20.8 \\
0.57 & 0.056 & 30 & 882 & 0.28 & 98 & 2.0 & 34.7 & 1.5 & 24.2 \\
0.74 & 0.095 & 40 & 1182 & 0.27 & 112 & 2.3 & 44.5 & 1.5 & 31.4 \\
0.9 & 0.121 & 50 & 1480 & 0.27 & 140 & 2.9 & 55.6 & 1.5 & 38.3 \\
1.12 & 0.139 & 60 & 1778 & 0.27 & 165 & 3.4 & 68.9 & 1.5 & 46.3 \\
1.3 & 0.150 & 70 & 2082 & 0.25 & 190 & 4.0 & 78.2 & 1.5 & 54.0 \\
\hline \hline
\end{tabular}

Pada hasil percobaan seperti pada tabel 6 didapatkan bahwa pada saat motor induksi dioperasikan dengan tegangan dan kecepatan yang berubah - ubah sesuai dengan V/f konstan maka nilai dari arus output rms inverter tetap sama yaitu sebesar 1.5 A. Perbandingan hasil pengujian arus output rms dapat dilihat pada gambar 15(a) hingga 15(d). Arus yang diserap inverter akan semakin meningkat seiring dengan bertambah cepatnya kecepatan motor induksi sehingga daya pada inverter semakin besar ketika motor induksi dioperasikan semakin cepat.

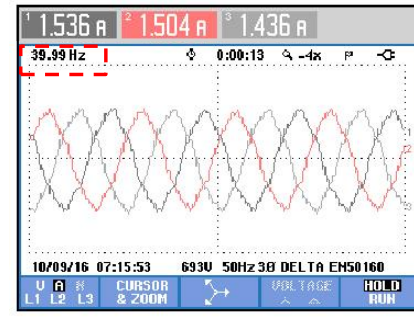

(a)

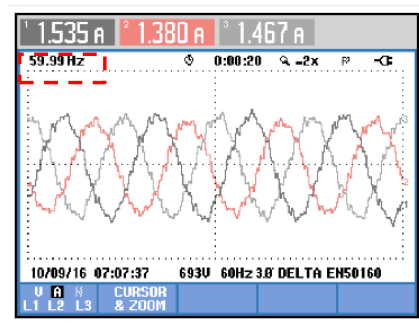

(c)

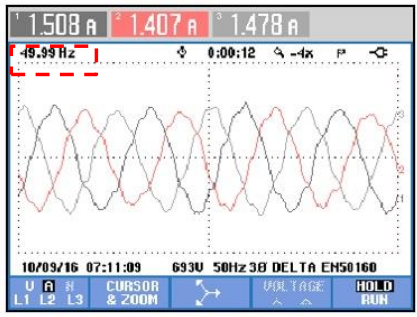

(b)

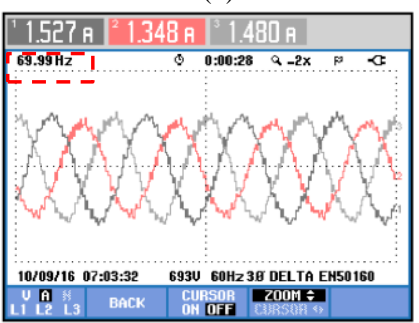

(d)
Gambar 15(a). Gelombang Arus Output pada Frekuensi $40 \mathrm{~Hz}$, Gambar 15(b). Gelombang Arus Output pada Frekuensi $50 \mathrm{~Hz}$, Gambar 15(c). Gelombang Arus Output pada Frekuensi 60 Hz, Gambar 15(d). Gelombang Arus Output pada Frekuensi $70 \mathrm{~Hz}$

Nilai shoot through duty ratio yang dibutuhkan semakin naik seiring dengan naiknya frekuensi fundamental. Hal ini untuk mendapatkan tegangan output sesuai perbandingan V/f konstan seperti pada gambar 16. Namun, nilai shoot through duty ratio yang dibutuhkan pada saat impelementasi tidak sesuai dengan hasil teori perhitungan. Hal ini dikarenakan adanya fenomena self boost pada Z-Source Inverter.

Kecepatan motor induksi pada saat frekuensi fundamental diubah - ubah. Pada hasil implementasi besar kecepatan motor induksi telah sesuai dengan teori yang ada dimana kecepatan motor induksi akan mendekati kecepatan sinkronnya pada saat tanpa pembebanan.

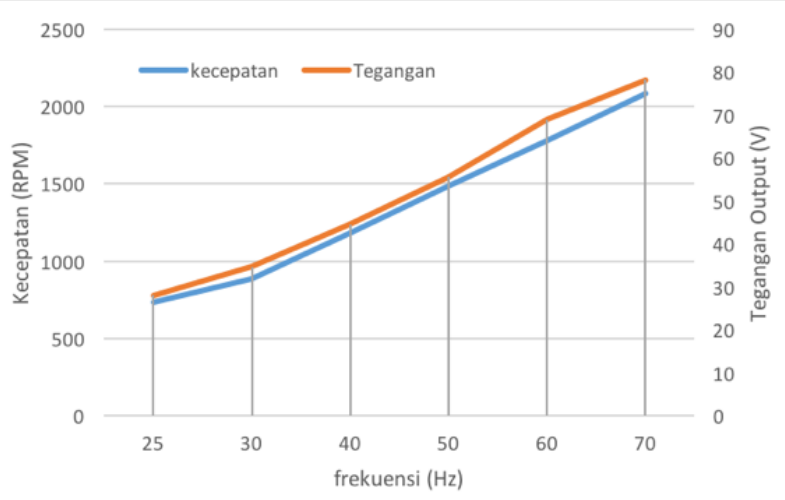

Gambar 16. Karakteristik V/f Konstan pada Z-Source Inverter sebagai Kontrol Kecepatan Motor Induksi 3 Fasa

\section{KESIMPULAN}

Berdasarkan pengujian yang telah dilakukan terhadap simulasi dan implementasi Z-Source inverter dengan metode simple boost control untuk suplai motor induksi 3 fasa dapat disimpulkan menjadi beberapa hal sebagai berikut:

1. Topologi Z-Source inverter dengan metode simple boost control dapat menaikan tegangan dengan tanpa adanya penambahan topologi lain.

2. Pada implementasi tegangan keluaran Z-Source inverter mengandung frekuensi fundamental dan frekuensi pensaklaran sedangan arus keluaran hanya mengandung frekuensi fundamental 
3. Arus keluaran Z-Source inverter pada saat diaplikasikan ke motor induksi 3 fasa memiliki harmonisa yang sangat kecil yaitu sebesar $2 \%$.

4. Pada implementasi Z-Source inverter akan menjadi mode DCM apabila diaplikasikan ke beban yang kurang dari $20 \%$ rating inverter.

5. Efisiensi Z-Source inverter yaitu sebesar $88 \%$.

6. Z-Source inverter mampu menjadi kontrol kecepatan motor induksi 3 fasa (V/f konstan) dengan cara mengubah parameter shoot through duty ratio dan frekuensi fundamental.

7. Fenomena self boost muncul pada saat Z-Source inverter diberi beban yang memiliki faktor daya sangat rendah.

\section{SARAN}

Saran yang diberikan untuk perkembangan penelitian selanjutnya adalah:

1. Z-Source inverter sebaiknya diaplikasikan untuk beban yang memiliki faktor daya yang diatas 0.8 agar fenomena self boost dapat dihindari. [6,17]

2. Z-Source inverter sebaiknya diaplikasikan diatas $50 \%$ dari ratingnya agar terhindar dari mode DCM.

3. Z-Source inverter sebaiknya diberi tambahan filter pada sisi keluaran sehingga bentuk tegangan dapat berupa sinusoidal.

4. Kontrol penyalaan Z-Source inverter dapat menggunakan metode lainnya seperti maximum boost control maupun constant maximum boost control with third harmonic injection untuk mereduksi stress tegangan pada setiap komponen. $[8,9,10]$

5. Penambahan snubber pasif atau aktif pada Z-Source inverter dapat dilakukan untuk mengurangi spikes tegangan pada MOSFET. [11,18]

6. Komponen induktor pada Z-Source inverter dapat diganti dengan induktor terkopel untuk memperingkas dan menghemat biaya pembuatan. [17]

\section{DAFTAR PUSTAKA}

[1] Gajanayake, C.J., Vilathgamuwa, D.M., et al: 'Z-Source Inverter Based Flexible Distributed Generation System Solution for Grid Power Quality Improvement'. IEEE Trans on Energy Conv., Vol. 24, No.3, pp. 695-703, September 2009.

[2] Peng, F.Z. Shen, M., Holland K., 'Application of Z-Source Inverter for Traction Drive of Fuel Cell-Battery Hybrid Electric Vehicles'. IEEE Trans Power Electron, Vol. 22, No.3, pp. 1054-1061. May 2007.

[3] Peng, F.Z. 'Z-Source Inverter'. IEEE Trans. Ind. Appl., 2003. Vol. 39, pp.504-510

[4] Rashid, M.H. 'Power electronics: circuit devices and applications'. (Prentice Hall), 1993

[5] Mohan, N., Undeland, T.M., and Robbins, W.P. 'Power Electronics: Converters, Applications, and Design'. Canada. 1995. John Wiley \& Sons, Inc.

[6] Hanif, M., Basu, M., Gaughan, K. 'Understanding the Operation of a Z-Source Inverter for Photovoltaic Application with a Design Example'. IET Power Electron. 2011. Vol. 4. Iss. 3. Pp. 278- 287

[7] Loh, P.C., Vilathgamuwa, D.M., Lai, Y.S., Chua, G.T., et al.: 'Pulsewidth modulation of Z-source inverters'. Industry Applications Conf., 39th IAS Annual Meeting, 3 - 7 October 2004, pp. 148 - 155

[8] Peng, F.Z., Shen, M., Qian, Z.: 'Maximum boost control of the Zsource inverter', IEEE Trans. Power Electron., 2005, 20, (4), pp. 833 $-838$

[9] Shen, M., Wang, J., Joseph, A., Peng, F.Z., Tolbert, L.M., Adams, D.J.: 'Maximum constant boost control of the $\mathrm{Z}$ source inverter'. Proc. IEEE IAS '04, 2004, p. 147

[10] Pham C.T, Shen A, Dzung P.Q, Anh N.B, and Phu N.X., 'A Comparison of COntrol Methods for Z-Source Inverter'. Scientific Research., Energy adn Power Engineering., no. 4, pp. 187-195, June 2012.
[11] Haiping, X., Peng, F.Z., Lihua, C., et al: 'Analysis and Design of BiDirectional Z-Source Inverter for Electrical Vehicles'. 23 ${ }^{\text {rd }}$ Annual Applied Power Electronics Conf. and Exposition, 2008. APEC 2008, 2008, pp. 1252-1257

[12] Chapman, S. J.: 'Electric Machinery Fundamentals $4^{\text {th }}$ ed'. New York. 2005. The McGraw-Hill Companies.

[13] Qahhar, M., Riawan, D.C., Asfani, D.A., 'Penurunan Rating Tegangan pada Belitan Motor Induksi 3 Fasa Dengan Metode Rewinding Untuk Aplikasi Kendaraan Listrik'. Tugas Akhir., Institut Teknologi Sepuluh Nopember., Juli 2013.

[14] Diana L.R., "Practical Magnetic Design: Inductors and Coupled Inductors"., IEEE., pp 1-20.

[15] TDK., "Ferrites and Accessories E65/32/27"., EPCOS AG, June 2013.

[16] TDK., "Ferrites and Accessories SIFERRIT material N27"., EPCOS AG, September 2006

[17] 'Z-Source inverter for fuel cell vehicles', prepared by Oak Ridge National Laboratory, Mitch Olszewski, Program Manager, for Energy Efficiency and Renewable Energy, FreedomCAR and Vehicle Technologies, Vehicle Systems Team, Susan A. Rogers, Technology Department Manager, September 2005

[18] Shuai, D., Qianfan, Z., Chaowei, Z.: 'Analysis and Design of Snubber Circuit for Z-Source Inverter Applications'. IET Power Electron. vol. 9, iss. 5, pp. 1083-1091. December 2015. 